\title{
Role of food safety in procedures adopted for the purchase of minimally processed and fresh vegetables by foodservices
}

\author{
Segurança alimentar e o processo de aquisição de hortaliças in natura $e$ \\ minimamente processadas por serviços de alimentação
}

Kátia Regina Martini RODRIGUES ${ }^{1}$, Elisabete SALAY

\begin{abstract}
This research was designed to analyze whether the procedures adopted by foodservice establishments for the purchase of minimally processed and fresh vegetables favor the acquisition of safe products. This research investigated the purchasing policies of such establishments, whether self-managed or administered by foodservice contractors, in the municipality of Campinas and its outlying districts. A random sample of thirty-nine establishments participated in the research. The instruments for data collection were pre-tested, and the actual interviews were conducted by trained personnel. Comparative analyses were made using various statistical tests. All of the participating establishments purchase fresh vegetables, although only six of them use minimally processed ones. For most of the establishments, price is at least one of the most important criteria for the selection of a supplier, and they do not normally monitor the safety of the fresh products purchased (51.3\%), nor do they make regular technical visits to guarantee quality (46.2\%); moreover, most do not carry out a supplier development program. It is suggested that routine technical visits to suppliers should be adopted, as well as the creation of courses, such as those dealing with the safety of vegetables and supplier development, to be offered to foodservices.

Keywords: fresh vegetables; food safety; minimally processed vegetables; foodservice.
\end{abstract}

\section{Resumo}

Esta pesquisa teve como objetivo analisar se os procedimentos utilizados para aquisição de hortaliças in natura e minimamente processadas nas Unidades de Alimentação e Nutrição (UANs) favorecem a compra de produtos seguros. Sua abrangência foi o município de Campinas e seus quatro distritos e direcionou-se para UANs administradas por autogestão ou concessionárias de alimentos localizadas através de listagens fornecidas por entidades representativas da categoria. Foram identificados 60 casos e, desses, 39 participaram da pesquisa. Utilizaram-se instrumentos para a coleta de dados previamente testados e as entrevistas foram realizadas por pessoal treinado. Foram realizadas análises comparativas por meio de diferentes testes estatísticos. Todas as unidades faziam uso de hortaliças in natura e apenas seis de minimamente processadas. Grande parte das empresas não promoveu o desenvolvimento do fornecedor, poucas realizavam visitas técnicas (46,2\%) e monitoramento da segurança do produto in natura $(51,3 \%)$ junto ao fornecedor. Entre os critérios mais importantes para definição do fornecedor de hortaliças, o preço obteve grande destaque. Sugere-se que seja incorporada rotineiramente a visita aos fornecedores de hortaliças. Recomenda-se a criação de cursos na temática de segurança de hortaliças e desenvolvimento de fornecedores voltados ao setor de serviços de alimentação.

Palavras-chave: hortaliça in natura; alimento seguro; hortaliça minimamente processada; serviço de alimentação.

\section{Introduction}

Collective meals produced by foodservice establishments account for a large segment of the commercialized food market, and this number are in clear expansion. Since quality control of raw materials is extremely important in the prevention of food poisoning, foodservice establishments should be motivated to implement efficient systems for monitoring them, especially during production, transport, and the reception of raw materials at the institution (LIMA; GOES, 1999).

Suppliers clearly play a fundamental role in the quality of the services offered by foodservice establishments. A good supplier should provide high quality products at competitive prices with enough agility to deal with emergency situations, since, no matter how carefully one plans the menu, simple changes in temperature can alter the preference of users and generate demands other than those expected. On the other hand, food processing establishments can influence their suppliers. Since they buy large quantities of food, they can demand certain standards of quality, and these requirements should provide incentives for the improvement of the quality of all products furnished by that supplier. Moreover, such an improvement should be reflected throughout the entire productive food chain.

Consumer demands for food quality have increased over the years. There is also a growing concern with the nutritional

Recebido para publicação em 1/6/2009

Aceito para publicação em 25/9/2009 (004228)

${ }^{1}$ Faculdade de Nutrição, Pontifícia Universidade Católica de Campinas - PUC, Av. John Boyd Dunlop, s/n, Jd. Ipaussurama, CEP 13060-904, Campinas - SP, Brasil

${ }^{2}$ Departamento de Alimentos e Nutrição, Faculdade de Engenharia de Alimentos, Universidade Estadual de Campinas - UNICAMP, Rua Monteiro Lobato, n. 80, CP 6121, CEP 13083-862, Campinas - SP, Brasil, E-mail: salay@fea.unicamp.br

${ }^{*}$ A quem a correspondência deve ser enviada 
aspects of the diet. Since fresh vegetables are a source of vitamins, minerals, and fibers and decrease the risk of certain nontransmissible chronic diseases, their consumption is encouraged by the Brazilian Department of Health (BRASIL, 2006). In addition, the World Health Organization (2009) considers foodservice companies a significant agent in promoting healthy diets in the context of global strategy on diet, physical activity, and health. Fresh vegetables are thus present on the daily menu of foodservice establishments. Since they are perishable, however, a constant supply is necessary. Although daily delivery is often necessary, this can be reduced to three times per week if storage facilities permit. Moreover, such products are quite seasonal and fluctuate widely in price and quality as a function of weather conditions throughout the year.

Various studies have investigated the kind of quality control program adopted by foodservices in Brazil (AKUTSU et al., 2005; GENTA; MAURÍCIO; MATIOLI, 2005; CAVALLI; SALAY, 2004; BUCHWEITZ et al., 2003); although, few have looked specifically at the supply of fresh vegetables for foodservice establishments. One of these (SCHNEIDER, 2006) verified a lack of specific guidelines for the supply of such products, and suggested that the failure to adopt requirements satisfying health and safety concerns in the purchasing policies of the 33 hospital foodservices in the city studied (Porto Alegre, in the State of Rio Grande do Sul) had put the health of the consumers at risk.

Since so few studies investigate the safety of fresh vegetables in the policies adopted by foodservice establishments, the present paper was designed to analyze the purchasing policies for such fresh and minimally processed vegetables adopted by foodservice establishments, both the autonomous and those administered by food contractors, to ascertain whether these favor the purchase of safe produce.

\section{Methodology}

The municipality chosen for this study was that of Campinas, located in the State of São Paulo; it includes four outlying sub-districts of Souzas, Barão Geraldo, Aparecidinha and Joaquim Egydio. Campinas has a population estimated at $1,061,290$, with $98.33 \%$ living in urban areas. The municipality has an area of $795.70 \mathrm{~km}^{2}$, with a demographic density of $1,333.78$ inhabitants $/ \mathrm{km}^{2}$. In 2007, 1,932 companies were registered, and they supplied 62,011 jobs. A total of 1,555 hospital beds were available for recipients of national health care benefits (Unified Health Services or SUS), a ratio of 1.55 per 1,000 inhabitants in 2003. In that year, the city had 57 basic health care units (FUNDAÇÃO... 2009).

A variety of different kinds of foodservice establishments were selected to be included in this survey, including both public and private institutions; all had in common the regular serving of collective meals, and none of them received donations of fresh vegetables. With regard to the institutions which hire foodservice contractors, those were interviewed.

Since no list of foodservice establishments was available, the authors contacted the Program of Food for Workers and the Brazilian Association of Collective Meal Suppliers, which are quite representative of such establishments, for suggestions, as well as the Regional Council of Dietitians, since those organs maintain a register of foodservice establishments. The telephone directory was also consulted, as well as data provided by the Union of Workers in Collective Meal Companies. This procedure was similar to that adopted by Buchweitz (2001) and Savio et al. (2005).

Sixty establishments responsible for the serving of collective meals in the municipality of Campinas or which are headquartered there were located: 40 food contractors, 14 traditional hospital foodservice establishments, and six self-managed institutional foodservices of other types. Given this population of 60 establishments and setting a confidence level of $90 \%$ (considered acceptable due to the difficulty of conducting this kind of research), with a population frequency estimated at $90 \%$ and a margin of error of $5 \%$, a sample size of 38 establishments was determined (COCHRAN, 1977). Thirty-nine companies were thus randomly selected for interviews ( 22 food contractors and 17 autonomous institutional foodservice establishments, including hospitals, companies, and universities. When one establishment refused to collaborate, it was excluded and another one was randomly selected to replace it.

The collection of data from the foodservice establishments took place between the months of December of 2004 and May of 2005, and the person interviewed was the one responsible for the certification of suppliers or for the purchase of fresh vegetables. Two undergraduate students of the Faculty of Food Engineering of the State University of Campinas were hired from the student-administered Junior Company for Food Consultation and trained to administer the interviews.

The instrument consisted of both open and closed questions, and the main topics involved the classification of the food establishment or foodservice contractor and the policy used for the supply of vegetables. This questionnaire had been previously tested to maximize reliability.

The quantitative data of the research were organized in a data bank in Microsoft Excel, 2003, and descriptive statistics such as percentages and averages were computed. Comparative analyses were then made using a Chi-squared test or a Fisher Exact Test to measure the association of the variables in the study and a non-parametric Kruskall Wallis test, followed by a Dunn multiple comparison test were also used, and a confidence level of $95 \%$ was adopted. The statistical software programs used for the analyses were XLSTATE 2006 and MINITAB for Windows, version 14.2.

\section{Results and discussion}

Most of the people interviewed had college education, and 10 have obtained additional education and hold a specialist degree. Most of the 39 establishments included in the study were food contractors (56.4\% companies) or autonomous hospital foodservices (30.8\%). Most served a maximum of 600 meals per day; although, some served between 601 and 3,000 (Table 1).

A ranking of the largest food suppliers in Brazil, published by the Brazilian Association of Food Companies, reported the existence of 34 companies which serve a large number of daily 
meals (DONNA, 2005). Of the eleven supplying 50,000 or more meals per day, eight administer foodservice establishments in the municipality of Campinas. Five of these establishments account for $40 \%$ of the collective meal market in Brazil, and four of them operate in Campinas. It was thus concluded that Campinas is a good target for the study of the policies of largescale food contractors in Brazil.

This research investigated the frequency with which fresh and minimally processed vegetables were used by foodservices. The national legislation states that fresh consumable products must be hygienized to reduce superficial contamination, using products approved by the Department of Health avoiding leaving residues from the hygienic product in prepared foods (BRASIL, 2004). The State of São Paulo legislation specifies that fresh vegetables must be hygienized by careful washing in drinking water in the foodservice establishment prior to serving, and if they are to be consumed raw they must be disinfected by immersion in a chlorate solution for 15-30 minutes, followed by rinsing in drinking water (SÃO PAULO, 2008). The legislation also specifies that these procedures must be conducted by trained workers in an adequate location.

Minimally processed vegetables, on the other hand, are fourth generation foodstuffs (PROENÇA, 2000) and arrive in the establishment already washed and ready to serve. The classification refers to the fact that the vegetables have already been peeled, hygienized, and cut. Recently, a specific norm for identity and quality patterns of minimally processed and freshcut vegetables was published (SÃO PAULO, 2009). Certainly, this norm will facilitate the quality control of these products, bringing gains to the industry and to consumers.

Of the 39 establishments studied, only 6 (15.4\%) used two or more kinds of minimally processed vegetables, which shows

Table 1. Characteristics of foodservice establishments interviewed in Campinas and outlying districts including type of administration, size of unit, and education of person responsible for selection of suppliers. SP, 2004/2005.

\begin{tabular}{lrc}
\hline \multicolumn{1}{c}{ Type of administration } & $\mathrm{n}$ & $\%$ \\
\hline Self-management in hospitals* & 5 & 12.8 \\
Other autonomous unit & 12 & 30.8 \\
Foodservices contractors & 22 & 56.4 \\
Number of meals per day served by the & & \\
estabishments interviewed & 22 & 56.4 \\
Up 600 & 9 & 23.1 \\
From 601 to 3,000 & 4 & 10.3 \\
From 3,001 to 10,000 & 2 & 5.1 \\
From 10,001 to 100,000 & 2 & 5.1 \\
More than 100,001 & & \\
Person responsible for selection of suppliers & & \\
Level of education & 10 & 25.6 \\
Specialist & 20 & 51.3 \\
University degree & 9 & 23.1 \\
\hline Hight school & & \\
\hline
\end{tabular}

*In the hospitals, information collected included the number of meals served to patients for lunch and dinner, as well as to accompanying persons and hospital employees. that such products have low insertion in the market segment. Two of those were foodservice contractors and the others were autonomous institutional foodservices (two of the latter being hospitals). Two additional establishments did work with one type of minimally processed produce, nevertheless, it was not served as a fresh vegetable, but rather used as a seasoning in the preparation of foods, and the establishments were eliminated from this consideration.

Minimally processed vegetables have been shown to be subject to problems with microbiological contamination (BONNAS et al., 2005; BRUNO et al., 2005; FURNALETO; SANTINI; VELASCOS, 2005; OLIVEIRA et al., 2005; SANTOS, 2007). Quality control of such products is certainly critical. An attempt was thus made to understand the aspects considered to be the most important in the selection of a supplier for fresh produce, including that which has undergone minimal processing. Interviewees were given a list of 15 options and asked to indicate the five most important involved in their selection of suppliers (with 1 for the most important and 5 for the least). Other criteria deemed pertinent could be included, if desired (Table 2).

Table 2 shows the conversion of the raw data to weighted scores and the significance of the differences observed. The number of establishments indicating each of the evaluative ratings (from 1 for "most important" to 5 for "least important") for each of the criteria is indicated. This overall evaluation was then weighted, with an evaluation of 1 being given a weight of 5 (the "most important") and one of 5 (least important) given a weight of 1 ; the result is then divided by 100 , to give a single weighted score for each criterion, and this was used for the statistical analysis. The criteria for the purchase of minimally processed vegetables could not be analyzed statistically given the extremely limited number of establishments purchasing them.

Price was clearly the most important criterion considered for the selection of suppliers of both fresh and minimally processed vegetables. An evaluation of the physical installations of the supplier did, however, seem to be less important for the selection of suppliers of fresh vegetables than for minimally processed ones.

None of the other 15 original options proposed for the selection of a supplier were considered to be important by any of the establishments investigated and have consequently been omitted from the table. These were: a) ease of deliver by supplier; b)ease of payment; c) previous evaluation of production conditions; d) reputation of supplier in the market; e) kind of transportation; f) appearance; g) location for hygienization of boxes; $h$ )respect for food safety by practices such as the implementation of good production practices; i) agility in problem resolution; j) respect for food safety control via implantation of Hazard Analysis and Critical Control Points (HAPPCC) system ; k) food safety certification by purchasing establishment.

The production of vegetables is extremely complex, and the risk of food poisoning from such foodstuffs is recognized. Contamination can occur during various phases of the production chain. One of the major causes is related to the utilization of 
contaminated water for irrigation, either during the planting phase, or later for pre-washing. Such contamination is very likely to increase the number of bacteria, viruses, and enteroparasites present in the vegetables (HARRIS et al., 2003; SILVA; OLIVEIRA; STAMFORD, 2003; FALAVIGNA et al., 2005). Another source of contamination is related to the use of agricultural pesticides. This contamination can reach dangerous levels if the pesticide is used in a greater concentration than recommended, or if the expiration date of the product have not been observed (REZENDE, 2003; ARAÚJO, 2000). People can also contaminate fresh products, and those who will handle fresh produce must be trained to be aware of the importance of hygienic practices throughout the productive chain (FOOD..., 1998).

In vegetable production, the utilization of agricultural chemicals in quantities higher than recommended, expired, or unauthorized can cause contamination (REZENDE, 2003; ARAÚJO, 2000). The control of agricultural chemicals in production should be improved, due to contamination of vegetables, as well as ground and surface water. Good agricultural practices protect the quality of water and human and animal health.

Packaging also plays a fundamental role in the reduction of the microbial level (ROEVER, 1998). Wooden crates should be abolished, and legislation recommending this has been suggested; if returnable boxes are to be used, establishments should have an adequate location for their hygienization (BRASIL, 2002). Moreover, the hygienization conditions of the vehicle used for the transportation of the vegetables should be considered.

This study has revealed that the evaluation of the quality conditions of production, the hygienizaton of crates/boxes, and the implementation of quality control methods were not given much importance by the foodservice establishments surveyed; this suggests that actions designed by public health agents to promote the awareness of the risks involved in a failure to adopt safe practices during the production of fresh vegetables would be pertinent. Foodservice establishments should seek to purchase safer products, and if they did, this would have a positive effect on the food market. A program of quality control in foodservice establishments should include the quality of the suppliers. The most efficient way of promoting this would, according to Ferreira (2001), be the choice of suppliers that have implemented quality control systems in their companies.

For minimally processed foods, as mentioned above, the evaluation of the facilities of the food contractor tends to be considered important, possibly a reflection of the concern of establishments with the quality of a product which is supposedly ready for consumption upon purchase (Table 2).

This research has shown that most of the agreements between the suppliers of fresh and minimally processed vegetables, the food contractors, and foodservice establishments are of an informal nature (Table 3 ). This informality has also been recognized by Farina, Machado and Kalil (2000), who showed the importance of trust and commercial sanctions in market relations. However, they also point out that as quality requirements become more rigid, the tendency is to adopt more formal methods. Two of the people interviewed work for establishments linked to the public administration, and formal competitive bids must be submitted and evaluated before foods can be purchased.

The lack of a legally-binding instrument between the two parties can lead to the involvement of poor performing entities in the sector since suppliers who do not fulfill the requirements of the foodservice establishment simply lose their customers, and no further sanctions are imposed. On the other hand, some of the establishments pointed out the existence of long-term satisfactory arrangements with certain suppliers, some of which have lasted for up to 10 or 20 years.

Most of the establishments investigated do not impose any special quality requirements perpetuating the lack of contracts

Table 2. Scores and frequency of application of criteria in the selection of suppliers of fresh and minimally processed vegetables, as reported by autonomous institutional foodservices and foodservice contractors in relation to the degree of importance indicated. Municipality of Campinas and outlying sub-districts; SP, 2004/2005.

\begin{tabular}{|c|c|c|c|c|c|c|}
\hline \multirow[t]{2}{*}{ Criterion } & \multicolumn{5}{|c|}{ Original rate ${ }^{*}$} & \multirow[t]{2}{*}{ Score ${ }^{\star *}$} \\
\hline & 1 & 2 & 3 & 4 & 5 & \\
\hline \multicolumn{7}{|l|}{ Criteria for fresh vegetables } \\
\hline Price & 12 & 9 & 5 & 3 & 3 & $12 \mathrm{~A}^{* * *}$ \\
\hline Availability of variety & 3 & 4 & 3 & 8 & 3 & $5.9 \mathrm{~B}$ \\
\hline Dependability of delivery & 3 & 5 & 4 & 5 & 1 & $5.8 \mathrm{BC}$ \\
\hline Criteria for minimally processed vegetables & & & & & & Score ${ }^{\star * * *}$ \\
\hline Price & 2 & - & 1 & 1 & 2 & 1.7 \\
\hline Pre-evaluation of physical installations of supplier & 2 & - & - & 1 & - & 1.2 \\
\hline Standardization of quality & 1 & 1 & 1 & - & - & 1.2 \\
\hline Availability of variety & - & - & 1 & 1 & - & 0.5 \\
\hline
\end{tabular}

*Sum of number of establishments evaluating criterion for each level of importance, with 1 indicating greatest importance ${ }^{\star *}$ calculated by weighting each of the " 1 " ratings as five, each of the " 2 " ratings as four, etc., and summing to get a total rating, which was then divided by 100; ${ }^{* *}$ criteria marked with the same letter do not differ significantly (results of KruskallWallis and Dunn Multiple Comparison tests); ${ }^{* * *}$ The limited number of establishments using such foodstuffs made statistical analysis impossible. 
between the parties. Since some intrinsic quality attributes of foods cannot be directly observed, systems guaranteeing quality must be adopted to protect the consumer. The existence of formal contracts tends to favor more tranquil business dealings, for both buyers and sellers, while the specification of products and processes leads to greater guarantees of food safety (HOLLERAN; BREDAHL; ZAIBEL, 1999). Larger companies do tend to sign formal legal contracts (Table 3). To verify the effect of strategies adopted by foodservice establishments to protect food safety on the productive chain of vegetables, the interviewees were asked if anything had been done to stimulate the projected development of improved conditions and services by their suppliers. Projected development is here understood as any change solicited by the buyer in an attempt to improve supplier performance and services, whether in the short or long run. One example would be the undertaking of a program such as the training of the personnel of a supplier in order to create the conditions necessary to more adequately supply the needs of the company. The adoption of such a policy might require the investment of time and money, but it should definitely culminate in advantages for both parties. The objective of such a program would not be limited to the making of immediate changes to reduce real or potential problems, but rather to increase the ability of the supplier to undertake its own changes (NEUMANN, 2002).

This survey has shown that only few of the establishments surveyed made demands for modifications by their suppliers as a condition for the continued purchase of fresh produce, with
$76.9 \%$ of the people interviewed reporting that no such demands had been made (Table 4). There was no association between the kind of administration and the setting of requirements designed to stimulate the projected development of suppliers so that improved products or services would be supplied (Fisher exact test; $\mathrm{p}=0.7042$ ). All of the 9 establishments reporting having required some sort of change had requested immediate technical changes, such as uniformity of delivery service, standardization of packaging, or modifications in transportation, and none had developed training courses for the suppliers and their personnel, nor were investments made in programs of cooperation which would improve the processes of the supplier.

The same type of information was also sought in relation to minimally processed vegetables. For one of the establishments surveyed, the person interviewed reported that the food contractor had started producing its own minimally processed products. Only one of the other five establishments using this kind of product mentioned the projected development of suppliers in order to provide better services, and what was requested was related to uniformity in delivery and the standardization of packaging. No requirements were made by any of the other four establishments.

The situation of minimally processed vegetables is the same as what is seen for fresh vegetables. No requirements designed to stimulate changes which would contribute to long-range improvements in the services were reported. Even though, such

Table 3. Types of commercial arrangements among suppliers of fresh and minimally processed vegetables and autonomous foodservices / foodservice contractors in the municipality of Campinas and outlying sub-districts; SP, 2004/2005.

\begin{tabular}{|c|c|c|}
\hline For fresh vegetables & $\mathrm{n}$ & $\%$ \\
\hline Partnership with supplier & 23 & 59.0 \\
\hline Formal contract & 4 & 10.3 \\
\hline Purchase directly from CEASA, and partnership & 3 & 7.7 \\
\hline Formal open bid & 2 & 5.1 \\
\hline Retail store and partnership with supplier & 2 & 5.1 \\
\hline Total & 39 & 100.0 \\
\hline \multicolumn{3}{|l|}{ For minimally processed vegetables } \\
\hline Partnership with supplier & 3 & 50.0 \\
\hline Formal contract & - & - \\
\hline \multicolumn{2}{|c|}{ Predominant kind of commercial arrangements in relation to mumber of meals served } & $\mathrm{n}(\%)$ \\
\hline Up to 600 meals - 22 establishments & Partnership with supplier & $13(59.1)$ \\
\hline From 601 to 3,000 meals - 9 establishments & Partnership with supplier & $6(66.7)$ \\
\hline From 3,001 to 10,000 meals - 4 establishments & Partnership with supplier & $3(75.0)$ \\
\hline \multirow[t]{2}{*}{ From 10,001 to 100,000 meals - 2 establishments } & Partnership with supplier & $1(50.0)$ \\
\hline & Formal contract & $1(50.0)$ \\
\hline More than 100,000 meals - 2 establishments & Formal contract & $2(100.0)$ \\
\hline
\end{tabular}

\footnotetext{
${ }^{*}$ According to the person interviewed, the suppliers provide the vegetables for the foodservice establishment, and in exchange for it they receive the advertisement of their company
} at events promoted by the establishment. 
a policy would certainly benefit both parties. Approximately half of the companies surveyed did, however, feel that they monitored the safety of the fresh vegetables supplied (Table 4).

There is no association between the type of administration and the monitoring of the safety of fresh vegetables (Chi-Squared Test; $\mathrm{p}=0.855$ ). Technical visits were made to monitor the safety of vegetables by 18 of the establishments interviewed (46.2\%); however, two establishments reported that they monitor the safety conditions of their suppliers without technical visits. Research conducted in hospitals in the municipality of Porto Alegre, in the State of Rio Grande do Sul, has found that most of these institutional foodservices do not make specific evaluations

Table 4. Projected development and monitoring of suppliers of fresh and minimally processed vegetables by autonomous foodservices and food contractors in an attempt to guarantee the safety of the food supplied, Municipality of Campinas and outlying sub-districts; SP, 2004/2005.

\begin{tabular}{|c|c|c|c|c|}
\hline \multirow{3}{*}{$\begin{array}{l}\text { Projected development and monitoring of } \\
\text { suppliers of fresh and minimally processed } \\
\text { vegetables }\end{array}$} & \multicolumn{4}{|c|}{ Type of administration } \\
\hline & \multicolumn{2}{|c|}{ Contractors } & \multicolumn{2}{|c|}{ Autonomous } \\
\hline & $\mathrm{n}$ & $\%$ & $\mathrm{n}$ & $\%$ \\
\hline \multicolumn{5}{|l|}{ For fresh vegetables ${ }^{*}$} \\
\hline Projected development of suppliers & 6 & 27.3 & 3 & 17.6 \\
\hline $\begin{array}{l}\text { Monitoring of safety of vegetables from } \\
\text { suppliers }\end{array}$ & 11 & 50.0 & 9 & 52.9 \\
\hline Conduction of technical visits & 10 & 45.5 & 8 & 47.1 \\
\hline \multicolumn{5}{|l|}{ Frequency of technical visits } \\
\hline Once for certification & 4 & 40.0 & 5 & 62.5 \\
\hline Monthly, or every two to three months & 3 & 30.0 & - & - \\
\hline Once a year & 1 & 10.0 & 1 & 12.5 \\
\hline Twice a year & - & - & 1 & 12.5 \\
\hline No specific frequency defined & 2 & 20.0 & 1 & 12.5 \\
\hline \multicolumn{5}{|l|}{ For minimally processed vegetables ${ }^{\star *}$} \\
\hline Projected development of suppliers & - & - & 1 & 33.3 \\
\hline $\begin{array}{l}\text { Monitoring of safety of vegetables from } \\
\text { suppliers }\end{array}$ & 1 & 50.0 & 3 & 100.0 \\
\hline Conduction of technical visits & 1 & 50.0 & 3 & 100.0 \\
\hline \multicolumn{5}{|l|}{ Frequency of technical visits } \\
\hline Once for certification & - & - & 2 & 66.7 \\
\hline Once a year & 1 & 100.0 & 1 & 33.3 \\
\hline $\begin{array}{l}\text { Relationship between technical visits } \\
\text { involving purchase of fresh vegetables and } \\
\text { number of meals served }\end{array}$ & & & & $\begin{array}{c}\mathrm{n} \\
(\% \text { total })\end{array}$ \\
\hline Up to 600 meals & & & & $7(31.8)$ \\
\hline From 601 to 3,000 meals & & & & $3(33.3)$ \\
\hline From 3,001 to 10,000 meals & & & & $4(100.0)$ \\
\hline From 10,001 to 100,000 meals & & & & $2(100.0)$ \\
\hline More than 100,000 meals & & & & $2(100.0)$ \\
\hline
\end{tabular}

*The percentages referring to projected supplier development, safety monitoring, and conduction of technical visits were calculated as a function of the number of establishments in which interviews were conducted (22 food contractors and 17 autonomous institutional foodservices). For the calculation of the percentages in relation to the frequency of technical visits, only those establishments mentioning monitoring were considered (10 food contractors and 8 autonomous institutional foodservices); ${ }^{* *}$ Only six of the establishments reported using minimally processed vegetables, with one food contractor informing that they produce their own; the percentages are thus based on the two food contractors and three autonomous institutional foodservices purchasing from a supplier. prior to signing a contract (SCHNEIDER, 2006), and similar data have been found in the present study.

The frequency of technical visits is actually quite important, yet of the 18 establishments reporting undertaking them, only 3 (11.1\%) do so as frequently as every $1-3$ months. Some $50 \%$ do so only once for certification, and two report that the norm is a single technical visit prior to certification although further visits will be undertaken if some sort of problem with the supplier arises (data not included in the table).

The regulation of the Center for Sanitary Vigilance of the Secretary of Health of the State of São Paulo (CVS 18) (SÃO PAULO, 2008) suggests that it is important to conduct technical visits to investigate the operational conditions of potential suppliers in relation to raw materials so that these suppliers can be evaluated and certified. The resolution 216 of the Collegiate Directory (BRASIL, 2004) leaves it up to the foodservice establishment what should be evaluated in the selection of suppliers of raw materials.

Only one of the five establishments purchasing minimally processed vegetables from a supplier reported not monitoring food quality and not making technical visits. Two of those which do make technical visits do so only for certification, whereas the other two do so every year. There is thus little control over the suppliers of minimally processed vegetables, and only one of them reports regularly sending products for microbiological analysis every 4 months.

Conducting technical visits to a supplier, reveals the concern of a foodservice establishment with the food items being purchased. The lack of information about the processing of the food (operational techniques, production practices, storage, and distribution, as well as the personal hygiene of the employees and the conditions of the environment and the food itself), increases the risk of purchasing a product which is not suitable for consumption. When products are purchased for immediate consumption without further treatment, such aspects of their production should be exhaustively analyzed.

The need for scheduling technical visits to the facilities of suppliers is also emphasized by Marinho and Amado Neto (2001) since these are necessary to provide a more complete view of the system and processes involved including whether a company has the capacity to produce foods which meet the quality specifications required. They suggest the use of a checklist to help in this evaluation.

\section{Conclusions}

The results of this research have shown that price is what usually determines the selection of a supplier of fresh and minimally processed vegetables. There are practically no formal contracts between buyers and sellers in a market regulated largely by trust and commercial sanctions. However, formal contracts are signed between supplier and foodservice contractor when the latter serve more than 100,000 meals per day.

In general, however, foodservice establishments play only a minor role (or no role at all) in the stimulation of safe practices throughout the productive chain of vegetables. Technical visits and microbiological analyses are rare, with the exception of the 
larger establishments which serve more than 3,000 meals per day since they do conduct frequent technical visits to their suppliers. No programs for the projected development of suppliers are adopted even though the foodservice establishments themselves would be better served if they did. There are no demands related to the provision of safe food, not even by the larger establishments. Extension courses in vegetable safety and the development of suppliers could, however, be created and publicized throughout the foodservice sector, which should foster improvements throughout the productive chain.

\section{Acknowledgements}

The authors are grateful to the Fund for Education, Research and Extension (FAEPEX) of the State University of Campinas for financing this study

\section{References}

AKUTSU, R. C. et al. Adequação das boas práticas de fabricação em serviços de alimentação. Revista de Nutrição, v. 18, n. 3, p. 419-427, 2005.

ARAÚJO, A. Impacto dos praguicidas na saúde: estudo da cultura do tomate. Revista de Saúde Pública, v. 34, n. 3, p. 309-313, 2000.

BONNAS, D. S. et al. Qualidade higiênico-sanitária de vegetais minimamente processados, comercializados no Município de Uberlândia, MG. Higiene Alimentar, v. 19, n. 133, p. 100-103, 2005.

BRASIL. Ministério da Agricultura, Pecuária e Abastecimento. Instrução normativa conjunta SARC/ANVISA/INMETRO $n^{\circ}$ 009, de 12 de novembro de 2002. Estabelece exigências para as embalagens de frutas e hortaliças frescas. Diário Oficial [da] República Federativa do Brasil, Brasília, DF, 14 nov. 2002. Seção 1, p. 30.

BRASIL. Ministério da Saúde. Guia alimentar para a população brasileira: promovendo a alimentação saudável. Brasília, 2006. 210 p. (Série A-Normas e manuais técnicos).

BRASIL. Resolução RDC n 216, de 15 de setembro de 2004. Dispõe sobre o regulamento técnico de boas práticas para serviço de alimentação. Diário Oficial [da] República Federativa do Brasil, Brasília, 16 set. 2004. Seção 1, p. 25-28.

BRUNO, L. M. et al. Avaliação microbiológica de hortaliças e frutas minimamente processadas comercializadas em Fortaleza (CE). Boletim do Centro de Pesquisa e Processamento de Alimentos, v. 23, n. 1, p. 75-84, 2005

BUCHWEITZ, M. R. D. Normas boas práticas de produção e de prestação de serviços e sistema análise de perigos e pontos críticos de controle em serviços de alimentação na região de governo de Campinas, situação da implementação e custos. 2001. 222 f. Tese (Doutorado em Ciência da Nutrição)-Faculdade de Engenharia de Alimentos, Universidade Estadual de Campinas, Campinas, 2001.

BUCHWEITZ, M. R. D. et al. Implementation and costs of good manufacturing practices norms and hazard analysis and critical control points systems in foodservices in the Campinas region, SP, Brazil. Foodservice Research International, v. 14, n. 2, p. 97-144, 2003.

CAVALLI, S. B.; SALAY, E. Food quality and safety control activities in commercial foodservice in the cities of Campinas (SP) and Porto Alegre (RS), Brazil. Foodservice Research International, v. 14, n. 4, p. 223-239, 2004.
COCHRAN, W. G. Sampling techniques. New York: John Wiley \& Sons, 1977.

DONNA, E. C. A nova distribuição para o foodservice brasileiro. São Paulo: Associação Brasileira das Indústrias de Alimentação, 2005.

FALAVIGNA, L. M. et al. Qualidade de hortaliças comercializadas no noroeste do Paraná, Brasil. Parasitologia Latinoamericana, v. 60, n. 3-4, p. 144-149, 2005.

FARINA, E. M. M. Q.; MACHADO, E. L.; KALIL, C. Regulamentação governamental e estratégias de negócio no mercado brasileiro de frutas e legumes frescos. In: BELIK, W; MALUF, R. S. (Orgs.). Abastecimento e segurança alimentar. Campinas: IE/UNICAMP; CPDA, 2000. p. 161-181.

FERREIRA, S. M. R. Controle de qualidade em sistema de alimentação coletiva. Higiene Alimentar, v. 15, n. 90-91, p. 35-48, 2001.

FOOD AND DRUG ADMINISTRATION. US. Department of Agriculture, Centers for Disease Control and Prevention. Guide to minimize microbial food safety hazards for fresh fruits and vegetables. Washington, D.C.: 1998.

FUNDAÇÃO SISTEMA ESTADUAL DE ANÁLISE DE DADOS. Governo do Estado de São Paulo, Secretaria de Estado de Economia e Planejamento. Informações municipais. São Paulo. Available from: <http://www.seade.gov.br/perfilmunicipal.htm>. Acess in: 30 Jan. 2009.

FURNALETO, L.; SANTINI, M. S.; VELASCOS, F. A. S. Análise microbiológica de vegetais e hortaliças minimamente processados. Higiene Alimentar, v. 19, n. 131, p. 68-71, 2005.

GENTA, T. M. S.; MAURÍCIO, A. A.; MATIOLI, G. Avaliação das boas práticas através de check list aplicado em restaurante self-service da região central de Maringá, Estado do Paraná. Acta Scientiarum. Health Sciences, v. 27, n. 2, p. 151-156, 2005.

HARRIS, L. J. et al. Outbreaks associated with fresh produce: incidence, growth, and survival of pathogens in fresh and fresh-cut produce. Comprehensive Reviews in Food Science and Food Safety, v. 2, n. 1 p. $78-141,2003$. Supplement.

HOLLERAN, E.; BREDAHL, M. E.; ZAIBEL, L. Private incentives for adopting food safety and quality assurance. Food Policy, v. 24, n. 6, p. 669-683, 1999.

LIMA, S. B. O.; GÓES, J. A. W. Avaliação das condições de entrega de gêneros alimentícios perecíveis em unidade de alimentação e nutrição da cidade de Salvador-Bahia. Higiene Alimentar, v. 13, n. 59, p. 10-17, 1999.

MARINHO, B. L.; AMADO NETO, J. Gestão da cadeia de fornecedores e acordos de parcerias. In: AMADO NETO, J. (Org.). Manufatura de classe mundial: conceitos, estratégias e aplicações. São Paulo: Atlas, 2001. cap. 1, p. 17-52.

NEUMANN, C. S. R. Desenvolvimento de fornecedores: um estudo de caso no setor de máquinas agrícolas. 2002. 100 f. Dissertação (Mestrado em Engenharia de Produção)-Programa de Pósgraduação em Engenharia da Produção, Escola de Engenharia, Universidade Federal do Rio Grande do Sul, Porto Alegre.

OLIVEIRA, A. M. C. et al. Avaliação da qualidade higiênico sanitária de alface minimamente processada comercializada em Fortaleza, CE. Higiene Alimentar, v. 19, n. 135, p. 80-85, 2005.

PROENÇA, R. P. Inovação tecnológica na produção de alimentação coletiva. 2. ed. Florianópolis: Insular, 2000.

REZENDE, C. L. A coordenação do sistema agroindustrial do tomate orgânico no Estado de São Paulo e o comportamento do consumidor. 2003. 94 f. Dissertação (Mestrado)-Programa de 
Pós-graduação Interunidades em Nutrição, Universidade de São Paulo, São Paulo, 2003.

ROEVER, C. Microbiological safety evaluations and recommendations on fresh produce. Food Control, v. 9, n. 6, p. 321-347, 1998.

SANTOS, T. B. A. Qualidade microbiológica de frutas e hortaliças minimamente processadas comercializadas na cidade de Campinas/SP. 2007. 97 f. Dissertação (Mestrado em Ciência dos Alimentos)-Faculdade de Engenharia de Alimentos, Universidade Estadual de Campinas, Campinas, 2007.

SÃO PAULO. Centro de Vigilância Sanitária. Portaria CVS -18, de 9 de setembro de 2008. Regulamento técnico sobre os parâmetros e critérios para o controle higiênico-sanitário em estabelecimentos de alimentos. Diário Oficial [do] Estado de São Paulo, São Paulo, SP, 11 set. 2008. Seção 1, n. 171, p. 25.
SÃO PAULO. Resolução SAA nº 42, de 19 de junho de 2009. Norma técnica para produtos hortícolas minimamente processados e frescos cortados. Diário Oficial [do] Estado de São Paulo, São Paulo, SP, 20 jun. 2009. Seção 1, n. 114, p. 53-55.

SAVIO, K. E. O. et al. Avaliação do almoço servido a participantes do programa de alimentação do trabalhador. Revista de Saúde Pública, v. 39, n. 2, p. 148-155, 2005.

SCHNEIDER, A. P. Fornecimento de hortifrutigranjeiros para unidades de alimentação e nutrição hospitalares. Ciência e Tecnologia de Alimentos, v. 26, n. 2, p. 253-258, 2006.

SILVA, C. G. M.; OLIVEIRA, A. M.; STAMFORD, T. L. M. Enteroparasitas em vegetais: uma revisão. Higiene Alimentar, v. 17, n. 107, p. 13-18, 2003.

WORLD HEALTH ORGANIZATION. Global strategy on diet, physical activity and health. Geneve. Available from: <http://www.who.int/ dietphysicalactivity/implementation/en/>. Acess in: 19 July 2009. 